\title{
A Fresh Look At Economic Value Added: Empirical Study Of The Fortune Five-Hundred Companies
}

Adnan M. Abdeen, (Email: aabdeen@calstatela.edu), California State University, Los Angeles G. Timothy Haight, (Email: thaight@calstatela.edu), California State University, Los Angeles

\begin{abstract}
Rapid and complex changes in the economic and business environment are posing serious challenges to today's business executives. Meeting these challenges requires effective measures for control and performance evaluation. This article focuses on the uses, benefits and limitations of economic value added (EVA) as a value creation measure. Calculation of this trendy measure is complicated because of the many adjustments needed to convert the generally accepted accounting principles (GAAP) based income to economic income. The article compares the performance of EVA user companies with non-user Fortune 500 companies for the years 1997 and 1998. It shows that users performance means profits as percentage of revenues, assets, and stockholders' equity were higher than the means of non-users. However, the means for 1998 earnings per share (EPS), EPS change from 1997 and EPS growth for the years 1988-1998 were lower for the EVA user companies. EVA will become less popular in its use as an instrument of control and performance evaluation. Therefore, the conclusion of this research is not in support of EVA use as a measure of value creation to stockholders.
\end{abstract}

\section{Introduction}

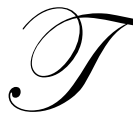

he economic and business environments have changed dramatically during the last few years. Business executives are faced with an increasingly competitive and complex environment. The need for creative leadership to handle the new developments in global business, technology, mergers, E-commerce and innovations is accelerating. According to Securities Data Co., (1999, p.48), " globally, more than $\$ 2$ trillion worth of mergers and acquisitions were announced in the first three quarters of 1999." The merger mania activities pushed executives for more efficiency in running their companies. Elimination of jobs and increases in spending on technology should help companies preserve profit margins. Furthermore, many companies are restructuring and focusing on what they can do best in offering high quality product and customer service. These developments call for a strategic management control system using accounting based performance measures as its central component. According to Konstans (1999, p.88) a recent survey of 1000 members of the Financial Executives Institute (FEI) ranked "control and performance evaluation" as number one of the top areas of importance for operating executives.

Given these developments in the business environment, companies need more powerful and sophisticated financial and non-financial indicators that measure performance. The traditional metrics used by managers over the years have become inadequate to run any business under this new environment. First class metrics, such as those listed in Table 1, are being introduced and greater attention is being paid to getting the accountants and the finance executives involved in planning, decision making and performance evaluation. Management is looking for a way to link earnings and related investment, not just for the company as a whole, but for the individual parts of the business. In addition, management is investigating ways to link its own interest to the interest of the shareholders.

Readers with comments or questions are encouraged to contact the authors via email.

Table 1

Performance Evaluation Metrics 


\section{$\underline{\text { Traditional Metrics }}$}

Earnings Growth

Earnings Per Share

Market Value

Return on Sales

Return on Assets

Total Return to Stockholders

Cash Flow

Assets Turnover

Inventory Turnover

Accounts Receivable Turnover

Capital Spending

Budget Comparisons

Cost Structure Improvement

Non-Financial Metrics $\underline{\text { First Class Metrics }}$

\section{Financial Metrics}

\author{
Value Based Metrics \\ Economic Value Added (EVA) \\ Value Based Management (VBM) \\ Market Value Added (MVA) \\ Cash Flow ROI (CFROI) \\ Discounted Cash Flow (DCF) \\ The balanced Scorecard
}

\author{
Market Share \\ Customer Loyalty \\ Increase in Customer Base \\ Capacity Utilization \\ Complexity Reduction \\ Order to Delivery Time \\ Diversity
}

High Quality Product/Services Customer Satisfaction Productivity Social Responsibility, Including Environment, Health \& Safety

These developments brought about the use of new techniques such as the economic value added (EVA), value-added management (VAM) market value added (MVA) and the balanced scorecard. EVA was given the most attention and companies such as AT\&T, Coca- Cola, Eli Lilly, Quaker Oats, Briggs and Stratton and others adopted EVA. These companies are considered the backbone of the United States economy. It seems that when companies adopt the philosophy of EVA, accountants, financial officers, treasurers, controllers and all the employees in finance and accounting have to change their job focus from that of historical recorders of business transactions to operational managers of assets and capital.

The purpose of this paper is to examine the basic concept of EVA and its fundamental uses, benefits and limitations. Furthermore, this paper presents an evaluation of the performance of the Fortune 500 corporations that cited the use of EVA in their 1997-1998 annual reports and/or 10-K Forms, in comparison with the performance of comparable non-EVA users. This paper will explore whether EVA is a valid and easy to understand metric for evaluating and improving management performance for the purpose of creating value for its shareholders.

\section{What Is Economic Value Added?}

Economic value added is a fashionable management performance measure pioneered by Stern Stewart \& Company, a management consulting firm. EVA emphasizes the residual wealth creation in a company after all costs and expenses have been charged including the firm's cost of capital invested. In its simplest terms, EVA measures how much economic value in dollars, the company is creating, taking into account the cost of debt and equity capital. EVA is simply calculated as follows:

$$
\left.\begin{array}{ll}
\begin{array}{l}
\text { Net Operating Profit } \\
\text { After Taxes }
\end{array} & \begin{array}{l}
\text { Weighted Average X Debt and Equity } \\
\text { Gost of Capital }
\end{array}
\end{array}\right\}
$$

EVA calculation relies on generally accepted accounting principles (GAAP) to measure past management decisions. Therefore, certain adjustments will have to be made in order to rectify any possible accounting distortions of income and investment. Examples of adjustments include research and development expenditures, and employee training costs that more correctly should be capitalized and amortized over their perceived years of future 
benefits. Capitalization of long-term non-cancelable leases that are treated as operating leases under SFAS No.13 is another example of an adjustment necessary to properly measure performance. An adjustment is also needed for amortization of these leases that will replace the rent expense. These and examples such as deducting the opportunity cost of capital from and adding the actual interest expense to the net operating profit after taxes must be made. The purpose of such adjustments is to convert the accounting income to the economic income. However, according to Mckenzie and Shilling (1998, p.60) too many adjustments may make EVA lose its meaning and potency.

The most difficult component of EVA to estimate is the cost of capital. The cost of capital represents the opportunity cost or the rate of return demanded by investors. It can be calculated by first estimating the individual cost of each source of financing (i.e., after-tax cost of debt, cost of preferred stock, and cost of equity.) Then after each of these cost components has been estimated the overall cost of capital is found by multiplying each individual source of capital by its relative market value as a percentage of the aggregate market value of all sources combined. The after-tax cost of debt is simply the bond's yield to maturity times one minus the firm's marginal tax rate. Since interest on debt is tax deductible, this adjustment must be made to properly reflect the true cost of the debt component. For example, if the firm's yield to maturity on its corporate debt is 8 percent and its marginal tax rate is $40 \%$, then the after-tax cost of debt would be 4.8 percent [8\%*(1- .40)]. Unlike debt, both preferred and common stocks' dividends are not deductible for tax purposes. Therefore, no tax adjustment is required. The cost of preferred stock can be found by dividing the annual dividend payment by the market value of the preferred stock issue. Thus, if a preferred issue paid annual dividends of $\$ 4.00$ per share and had a current market value of $\$ 40.00$ then its cost is $10 \%(\$ 4.00 / \$ 40.00)$. By far the most difficult component of the cost of capital to estimate is the cost of equity. There are several ways to estimate this component including dividend discount model, premium over long-term debt model, and the most frequently used, the capital asset pricing model (CAPM). The capital asset pricing model uses the market as a benchmark for estimating the cost of equity. It assumes that the cost of equity is simply a "risk free rate of return" plus a premium that investors require to take on additional market risk. The risk free rate of return can be thought of as a return that an investor will demand in the absence of risk. Here the investor receives a return reflecting the time value of money. A surrogate used to measure this component is typically the return on U.S. Treasury Bills. The firm's risk relative to the market is estimated using regression analysis. This provides an estimate of market risk, commonly referred to as beta. Beta measures the relative risk of the corporation's equity relative to that of the market. The market's beta is equal to one. A firm's beta may be less than, equal to or greater than the market's beta.

The following illustration will be used to show how the cost of equity is calculated. Assume that U.S. Treasury Bills are currently at 5\%. Assume further that the market return (S\&P 500) is expected to be 12\%. Finally, assume that the firm's beta is 1.5 . The firm's cost of equity can be estimated by using the following formula:

$$
\begin{aligned}
& \mathrm{R}_{\mathrm{I}}=\mathrm{R}_{\mathrm{f}}+\left(\mathrm{R}_{\mathrm{m}}-\mathrm{R}_{\mathrm{f}}\right) * \mathrm{~B}_{\mathrm{I}} \\
& \mathrm{R}_{\mathrm{I}}=5 \%+(12 \%-5 \%) * 1.5 \\
& \mathrm{R}_{\mathrm{I}}=5 \%+(7 \%) * 1.5 \\
& \mathrm{R}_{\mathrm{I}}=15.5 \%
\end{aligned}
$$

Where,

$$
\begin{aligned}
& \mathrm{R}_{\mathrm{I}}=\text { Cost of Equity } \\
& \mathrm{R}_{\mathrm{f}}=\text { Return on U.S. Treasury Bills } \\
& \mathrm{R}_{\mathrm{m}}=\text { Market return } \\
& \mathrm{B}_{\mathrm{I}}=\text { Firm's beta }
\end{aligned}
$$

The above formula yields a cost of equity of $15.5 \%$. Thus, the firm's higher market risk (i. e., $1.5>1.0$ ) results in a higher required return (i.e., 15.5\%>12\%). As this approach reveals, estimates of the risk free rate market return, and the firm's beta must be made in order to arrive at the cost of equity. Once all of the component costs have been estimated, the final step is to calculate a weighted average cost of capital by applying a weight to each individual component cost. For example, assume that the firm has a market value of $\$ 10,000,000$ ant that debt comprises $\$ 4,000,000$, preferred stock $\$ 2,000,000$, and equity the remaining $\$ 4,000,000$. Accordingly, the weight of debt would be $40 \%$, the weight for preferred stock would be $20 \%$, and the weight for equity would be $40 \%$. Given this information, the cost of capital would be calculated as follows: Ko $=(4.8 \%)(40 \%)+(10 \%)(20 \%)+(15.5 \%)(40 \%)$. 
Therefore, the overall cost of capital is 10.18 percent.

The use of an overall EVA is only appropriate if all units within the firm have identical risks. In instances where this is not true, the EVA of each division or project is more suitable. For example, Dayton Hudson, in their 1997 annual report stated that adjustments are made for the age of their stores, recognizing the mature stores inherently have higher returns than newly opened stores. Furthermore, the WAAC for the retail stores was determined to be 10 percent, while for the credit operations to be 6 percent as a result of its ability to support higher debt levels. Of course any returns over these percentages should produce EVA.

\section{Uses, Benefits, and Limitations}

The uses, benefits and limitations of EVA are presented in this paper with focus on decision making, performance evaluation, and incentive compensations.

\section{Decision-Making.}

The management decision-making process involves mainly the evaluation of investment and the allocation of the company's resources. The traditional process in making such decisions is based on cash flow and it is referred to as capital budgeting. EVA may be added now as an additional tool in making investment decisions that involves new projects, mergers and acquisitions. In this respect, EVA is close to net present value (NPV) technique. The use of cash flows as an important long-term indicator of shareholder value is based on discounting the cash flows in the same way as used in capital budgeting and determination of the worth of takeover targets. For example, the use of EVA in the decision should answer the question of whether the company being acquired will increase the value of the acquiring company and whether it will create additional value to the existing shareholders in the future. According to Aswath Damodaran (1998, p.5) in his research on value creation the EVA and cash flow return on investment might be simpler than traditional discounted cash flow valuation, but the simplicity comes at a cost that is substantial for high growth firms with shifting risk profiles. He stressed the importance of management's commitment to value enhancement and added that if managers truly care about value maximization then they can make almost any mechanism work in their favor.(1998, p.50) According to the Dow Theory Forecast (1999, p.1) some managers take a long-term view of value creation and consider capital and research and development spending of utmost importance for their firm future stability and its product development prospects. These managers are perceived by investors as bullish on the growth potential of their industry and the company they manage.

The recent popularity of EVA stems from the fact that managers are encouraged to make profitable investments since they are being evaluated on EVA target rather than the return on investment (ROI). When using ROI managers will be less enthusiastic about an investment opportunity or they may entirely reject any new investment that reduces their current or existing return on investment despite increasing EVA.

One of the distinguishing features of EVA is its application to areas where shareholder value is created. Disaggregation of data at the lower level of management and even at product line and individual customer levels can draw management's attention to where value is created or destroyed. Activities where EVA is maximized and where earnings can be increased at a faster pace than the increase in capital may be given more attention and activities where EVA is being destroyed can be discontinued. The objective of this approach to capital allocation is to ensure that line of business is constantly contributing to the improvement of the return on existing capital, seeking investments that create value to shareholders and maintaining optimal capital structure levels.

One of the major benefits of using EVA as a decision tool is in the area of asset management. For example, Coca-Cola made a decision to switch to cardboard soft drink concentrate shipping containers from stainless steel containers. The reusable stainless steel containers that sat on the company's balance sheet were written off very slowly. This helped increase profit and profit margins. In contrast, shipping concentrate in single-use cardboard containers would raise unit cost and reduce profits and the profit margin, but it would require very little investment of assets. The containers could be "expensed," or written off immediately. According to McClenahen (1998, p.65) when the EVA calculation was made, it was concluded that the freeing up assets on the balance sheet by switching 
to cardboard resulted in a capital charge that exceeded any shrinkage in profit. Another example of asset management was cited by Harnischfeger Industries Incorporated (1997, p.26), where EVA helped to maintain and sometimes reduce capital employed at times of increasing profits and sales. AT\&T adopted EVA in 1992 and dropped its use in favor of traditional measures in 1997. However, in its $199710-\mathrm{K}$, it continued to emphasize its policy to "mange the deployment and utilization of its assets in order to meet its global growth objectives while ensuring that these assets are generating economic value added for shareholders."

We may conclude that one of the major contributions of EVA is that management now pays greater attention to management of assets, allocation of resources, and capital structure including the operating leverage. Furthermore, EVA is appealing to developing companies that need to fund their projects through satisfying the value enhancement requirements of investors.

\section{Performance Evaluation}

The assessment of management performance brought about more use of financial and non-financial indicators. Ratios that are utilized heavily in the United States include return on assets, return on equity, return on sales, and return on investment (ROI). Comparable profits and ROI are still the most important criterion used by company executives to evaluate performance. According to Radebaugh and Gray (1997, pp.557-559) research shows that in other countries such as in Britain, emphasis is placed on the use of budget/actual comparisons and some form of ROI. In Japan, the use of sales and market share growth are the most important criterion in evaluating divisional and subsidiary managers.

The use of EVA in performance evaluation brought about a fresh approach as to how management should think. For example, in an EVA Brochure of the Millennium Chemicals Inc., a Subsidiary of Hanson, top executives consider the creation of value as their mission. Thus, they consider EVA, not only a tool for measuring value creation but a mind set, an attitude and a behavior. Moreover, they feel that EVA goes beyond traditional financial measures to show how they create value through improvements in sales and cost management as well as through managing business assets.

In assessing performance through the use of EVA, a target EVA for the creation of short-term and longterm wealth has to be established. The target EVA depends on the length of the business cycle and the time between receiving orders from a project to the time of delivery. When making the evaluation, actual EVA will have to be measured against target EVA and any deviations will have to be investigated and analyzed in order to know the reason for the deviation and if necessary to make appropriate corrective action. Whenever actual EVA exceeds target EVA, this indicates that management practices are creating more wealth than expected and wealth in this case will be shared between management and shareholders. Whenever actual EVA is less than target EVA, then management practices are not as good as expected. This process increases management effectiveness in staying focused on the interest of shareholders and the creation of their wealth. This process also provides feedback to executives at all levels, not concerning the actual measurement, but also concerning the assumptions used in establishing the target EVA. As a result, a shift or change in course of action may be necessary. On the other hand, this system may be intimidating to managers who are faced with situations beyond their control where risk is increased and consequently the firm's earnings are lowered. Management may consider leveraging their capital needs in order to reduce their cost of capital recognizing the fact that interest on debt is tax deductible. Such an EVA driven decision leads to creation of wealth.

The use of EVA could be extended to all levels of employees throughout the organization. When these employees, especially the sales employees, know that focusing on EVA will provide them with data that reveals margins on a specific product line or customer, then they will be prone to abandon measuring their effectiveness by volume alone and become more comfortable with the economic value approach. It has to be made clear to top executives that the success of the EVA system in performance evaluation depends a great deal on providing management employees with adequate tools that make the EVA approach successful. According to Kreger (1998, pp.79-80) this means authorizing managers to make decisions leading to new innovative ideas to create value. 


\section{Incentive Compensation}

Most companies that use the EVA approach tie management performance to executive compensation plans and to the expectations of shareholders. An examination of the annual reports of the Fortune 500 companies that use EVA revealed that these companies form a Performance-Based Awards Committee from a group of directors who are responsible for managing the performance awards plan. The Committee normally establishes performance targets that may be based on any of the performance metrics including EVA. As a condition of award payment, these targets should be met by the top executives of the company as a whole or by the executives of any of its subsidiaries, divisions or business units. The payment of the awards may be in cash (cash awards) or in common stock (stock performance awards). The Board of Directors establishes a maximum and a minimum amount of the awards and payments are made upon meeting pre-agreed targets.

According to Brabazon and Sweeney (1998, p.14) one of the major selling points of EVA is that its supporters suggest that a strong correlation exists between it and the share market value of the related company. When the stock value of a firm has gone up, it is viewed as having created value while one whose stock price has gone down has destroyed value. Even if markets are efficient, stock prices tend to fluctuate around the true value and markets are often inefficient. For this reason, firms may see their stock price goes up and their top management rewarded, even if the company destroyed value. The problem of using the market value of the company's shares as basis for compensation lies in the fact that it cannot be disaggregated beyond the firm level. Thus, it cannot be used to judge the managers of individual divisions of a firm, and their relative performance. Companies may understand the need to focus on value creation. However, they may remain suspicious of stock market gyrations. According to Damodaran $(1998$, p.50) the major problem is that whatever measure is used to compensate managers, they behave in order to look better on that measure even if that can be accomplished by reducing the value of the firm they manage. We may conclude that regardless of the measure used for incentive compensation, management should associate it with efficient operations, value added products and services, continuous improvement, cost reduction, and divestment of under-performing assets, innovation, customer satisfaction, and other non-financial measures.

\section{Research Design and Methodology}

The sample population consisted of the Fortune 500 corporations, the largest corporations in the United States, as published in the April 26, 1999 issue. The annual reports and /or 10-K Forms of these corporations were examined through search in the Internet, Lexis-Nexus database. Fortune evaluations include variables such as revenues, profits, assets, stockholders' equity, market value, earnings per share, and total return to investors. Fortune publishes only the median figures of these variables and for the purpose of this research it was necessary to calculate the means for evaluating the performance of the corporation using EVA and comparing that with the performance means of non-EVA corporations. Furthermore, Fortune rates the 500 companies not just on revenues, but on 12 other performance criteria by showing the highest 50 performing companies in each of the criteria. This research examines how many EVA users made the highest fifty companies lists in order to support or deny any conclusion may be reached about the EVA users. Fortune also ranks the corporations within industries and this research ranks the EVA users within the same industries in order to see which industry use this evaluation measure the most.

\section{The Findings}

Examination of the 1998/1997 annual reports and /or the 10-K Forms of the 500 companies revealed that only 47 companies (9.4 percent) specifically stated that they use EVA as a performance measure. Most of the 500 companies referred to shareholders value enhancement through profitable growth and the introduction of value added products, services, customers, advice, solutions, operations, Internet services and others. However, these companies were not considered EVA users, unless they specified the use of EVA by name or presented EVA calculations.

Forty-five of the 1997 or 1998 reports were not located in the database and instead the 10-K Forms were examined. The search failed to locate annual reports or 10-K Forms for 9 corporations who were mainly in the insurance industry. These 9 corporations were not excluded from the calculation of the performance means because they were considered as nonusers of EVA because the Fortune 500 companies include 39 insurance companies and 
none of the thirty examined use EVA.

Examination of Table 2, which summarizes the results of the performance means of both the EVA users and the 500 corporations reveals that the EVA users were ahead in every performance category except the 1998 earnings per share (EPS), the EPS change from 1997 and the EPS for the last 10 years, 1988-1998. Knowing the benefits of using EVA, it is surprising to find also that the performance mean for the 1998 total return to investors and the last 10 years, 1988-1998, annual return to investors were lower for the EVA users. It has to be revealed that the 1998 EPS Fortune used the new "diluted" EPS as called for by rule 128 of the Financial Accounting Standards Board (FASB) starting on December 15, 1997. Furthermore, total return to investors includes both price appreciation and dividend yield to an investor in the company's stocks.

Table 2

Comparison of Performance Mean of

\section{Fortune 500 Corporations EVA Users with Non-EVA Users}

\begin{tabular}{lccc} 
Performance Criteria & Mean of Non-EVA Users & & Mean of EVA Users \\
\cline { 2 - 3 } 1998 Revenues & $\$ 11,481.2$ Million & & $\$ 13,577$ Million \\
Revenues Change From 1997 & $16.01 \%$ & $17.90 \%$ \\
1998 Profits & $\$ 647.58$ Million & $-0.43 \%$ & $\$ 929.5$ Million \\
Profit Change From 1997 & $5.27 \%$ & $-15.40 \%$ \\
Profits as Percentage of Revenues & $3.80 \%$ & $5.60 \%$ \\
Profits as Percentage of Assets & $7.11 \%$ & $5.00 \%$ \\
Profits as Percentage of Stockholders Equity 12.18\% & $17.60 \%$ \\
1998 EPS & $-3.45 \%$ & $1.70 \%$ \\
EPS Change From 1997 & $6.79 \%$ & $-18.50 \%$ \\
EPS 1988-1998 Annual Growth Rate & $16.30 \%$ & $3.00 \%$ \\
1998 Total Return to Investors & $17.81 \%$ & $9.90 \%$ \\
1988-1998 Annual Return to Investors & & $15.50 \%$ \\
\multicolumn{2}{c}{ Source: } & Calculations Are Based on Data Published in Fortune, Volume 139, No.8,
\end{tabular}

Table 3 shows the number of EVA users included in highest 50 companies rated for 12 performance criteria. An examination of this Table reveals that out of the 47 companies very few made the list. The highest was 10 (21 percent) made the top market value criteria which means that those were among the largest companies of the 500 companies in terms of common share price times the number of shares outstanding on March 15,1999. The lowest number of EVA users that made the highest 50 companies in the category of 1998 greatest growth in earnings per share was only one ( 2 percent) and highest 1998 return to investors was 2 companies ( 4 percent). This fact confirms the disappointing lower performance means in the EPS and the total return to investors.

Table 3

EVA Users Included Among the 50 Highest Performing Fortune 500 Corporations

Performance in $1998 \quad$ No. of Corp. Listed Among the Highest 50 Performing Companies $\quad$ \% out of 47 EVA Users

Biggest Increases in Revenue

Highest Profits

Biggest Increases in Profits

Highest Returns on Revenues

Highest Returns on Assets

Highest Returns on Stockholders Equity

Highest returns to Investors (1year)

Highest Returns to Investors (10 years)

Greatest Growth in Earnings Per Share

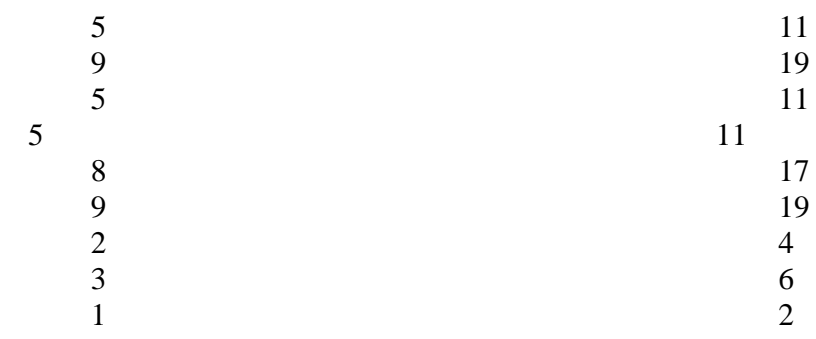


Highest Market Value

Most Assets

Biggest Employers

Source: Fortune Volume 139, No.8, pp. F-28 to F-32
10

5

5
21

11

11

An examination of the most EVA users categorized by industries in Table 4 reveals that the highest users are in the telecommunication and network communications ( 6 companies) and chemicals ( 6 companies) industries. The second most users are commercial banks ( 3 companies), food $\&$ food services $\&$ drug stores ( 3 companies), wholesalers ( 3 companies), 2 companies for each of forest and paper products, metals, petroleum refining, pharmaceuticals; scientific, photo, and control equipment; and waste management. Other industries either one or no EVA user was found.

\section{Conclusions and Recommendations}

The EVA literature suggests that EVA is a trendy tool for measuring management performance. However, other tools are appearing in the literature and the annual reports of the Fortune 500 companies such as value-based management, market value added, balanced scorecard and other non-financial measures. While several studies have been conducted, research for the balanced scorecard strategy implementation is still at its early stage.

The main problem with EVA is the calculation of its various elements, particularly the net operating income after tax and the average cost of capital. The fact that several adjustments are to be made in order to convert the GAAP based income to economic income make this performance metric complex. In some cases the number of adjustments may reach over one hundred and fifty. Using EVA for capital budgeting decisions has to be augmented with traditional metrics such as net present value, discounted cash flow, and payback period.

For performance evaluation of management, disaggregation of data used in EVA calculation is a very complex process, and in some cases, maybe considered unattainable objective. A recommended approach is to use one metric (EVA) for top-level executives and different metric for middle and lower level managers. In this respect the effect of using any metric on behavior of all levels of management should be taken into consideration, especially when designing incentive compensation plans.

Table 4

Fortune 500 Companies That Used EVA in 1998

Classified by Industries

$\underline{\text { Industry }}$

Companies Included In Fortune 500

Companies Used EVA

Telecommunications and Network Communications 15

Chemicals

14

Commercial Banks

Food, Food Services and Drug Stores

Wholesalers

Forest and Paper Products

Metals

Petroleum Refining

Pharmaceutical

Scientific, Photo and Control Equipment

Waste Management

Aerospace

Automotive Retailing and Service

Beverages

Electronics

Engineering and Construction

General Merchandisers

Motor Vehicles and Parts

Publishing and Printing

Rubber and Plastic Products

Securities

$\begin{array}{ll}5 & 6 \\ 4 & 6 \\ 26 & 3 \\ 1 & 3 \\ 2 & 3 \\ 3 & 3 \\ 8 & 2 \\ 5 & 2 \\ 0 & 2 \\ & 2 \\ & 2 \\ & 2 \\ & 1 \\ & 2 \\ 8 & 1 \\ & 1 \\ 4 & 1 \\ 1 & 1 \\ & 1 \\ 1 & 1 \\ 6 & 1 \\ & 1 \\ & \\ & 1\end{array}$




\author{
Special Retailers \\ Textiles \\ Toys and Sporting Goods \\ Utilities, Gas and Electric \\ All Other Industries \\ Total
}

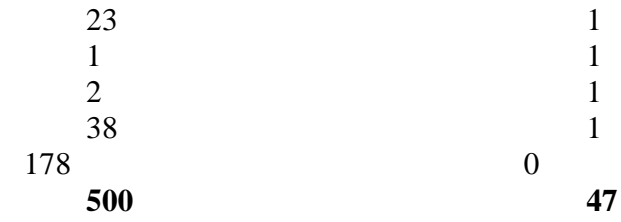

Source: Fortune, Volume 139, No.8, April 26,1999, pp. F-51to F-73.

When using EVA, the business cycle, the seasonal fluctuations, and the time between ordering and delivery of a product should be considered. The use of average EVA over 3-5 years, as a target is more beneficial and more realistic than using one year EVA. Whatever approach we use, consistency may reduce the effect of any volatile or unusual business or seasonal fluctuations in business activities.

The performance of the Fortune 500 companies using EVA, as revealed in this research, was better than the performance of the non-EVA users for the categories of profits as percentage of revenues, assets, and stockholders' equity. However, it was a lot worse for the EPS and the total return to investors. These results lead us to conclude that EVA will become less popular in its use as an instrument to measure value creation to stockholders and that EVA will join the other traditional metrics used by business firms.

\section{Suggestions for Future Research}

Since the use of EVA as a performance measure gained popularity in recent years, continued research in this area is needed. A survey of financial executives of companies using EVA would assure confidence in its use. Furthermore, such survey may reveal why few companies discarded the use of EVA as a management performance measure and as a value creation to shareholders.

\section{References}

1. Brabazon, Tony and Sweeney, Breda, "Economic Value Added-Really Adding Something New?" Accountancy, Ireland, Dublin, p.14, 1998.

2. Damodran, Aswath, "Value Creation and Enhancement: Back To The Future, FMA International, Contemporary Finance Digest, Vol. 2 No 4, pp.5-50, Winter 1998.

3. Dow Theory Forecast, “Companies With Confidence," Vol. 55 No.39, p.1, September 27, 1999.

4. $\quad$ Hanischfeger Industries Inc., Annual Report, p.26, 1997.

5. Konstans, Constantine, "Wanted: Management Accounting Skills," Strategic Finance, p.88, May 1999.

6. Kreger, Randi, "Creating Economic Value, Mortgage Banking, Washington, Vol.58, Issue 11, pp. 79-80, August 1998.

7. McClenahen, John S., "Accounting For Change," Industrial Week, Cleveland, p.65, September 21, 1998.

8. McKenzie, Francine and Shilling, Mathew D., "Avoiding Performance Traps: Ensuring Effective Incentive Design and Implementation," Compensation and Benefits review,Vol.30, Issue 4, p. 60, July/August 1998.

9. Radebaugh, Lee H. and Gray, Sidney J., International Accounting and Multinational Enterprises, Fourth Edition, New York, pp.557-559, John Wiley \& Sons, Inc.1997.

10. Securities data Co., Business Week, p.48, October 18,1999.

Notes 
